\title{
ЦИТОХІМІЧНА ТА ЦИТОЛОГІЧНА ХАРАКТЕРИСТИКА ПРОЦЕСІВ ДИФЕРЕНЦАЦІЇ БУКАЛЬНОГО ЕПІТЕЛІЮ В ОСІБ ЧОЛОВІЧОЇ СТАТІ МОЛОДОГО ВІКУ В НОРМІ
}

У статті наведено результати комплексного цитохімічного і цитологічного дослідження клітинного складу букального епітелію осіб чоловічої статі молодого віку в нормі. Отримані результати дають можливість констатувати переважання зрілих форм епітеліоцитів у цитограмах, що забезпечує, таким чином, бар'єрну функцію щоки шляхом незначної тенденції до зроговіння, ініціюючи десквамативні процеси епітелію даної анатомічної ділянки в обстеженого контингенту осіб.

КЛЮЧОВІ СЛОВА: епітеліоцити, клітини, цитоплазма, ядро, гранули.

Робота є фрагментом проекту Науководослідного інституту генетичних та імунологічних основ розвитку патології та фармакогенетики (м. Полтава) "Роль запальних захворювань зубо-щелепного апарату в розвитку хвороб, пов'язаних із системним запаленням" (номер державної реєстрації 0112U0011538). Автор є співвиконавцем даного проекту.

ВСТУП. Функціональний статус букальних епітеліоцитів, як і інших епітеліальних клітин, залежить від ступеня їх зрілості. У складі багатошарового плоского епітелію букальні епітеліоцити перебувають на різних стадіях морфофункціонального диференціювання - від малодиференційованих попередників у базальному шарі до високоспеціалізованих клітин, які в міру диференціювання зміщуються в поверхневі шари, підлягаючи десквамації. Частина 3 них має ознаки кератинізації $[2,3]$.

Диференційні та проліферативні процеси, а також функціональні параметри зрілих клітин регулюються факторами місцевого і центрального походження, що дає можливість оцінити гемостаз слизової оболонки порожнини рота за клітинним складом $[9,10]$.

Морфологічні зміни диференціювання епітелію запропоновано враховувати при скринінговому оцінюванні стану здоров'я, за умов стресогенних впливів, шкідливих факторів зовнішнього середовища, соматичної патології, біологічного віку людини $[4,5,8]$.

Якісні й кількісні зміни букальних епітеліоцитів $€$ індикатором порушень орального та ๑) Н. В. Гасюк, 2015. саліваторного гомеостазу, прогностичними та диференційно-діагностичними критеріями патологічних процесів слизової оболонки порожнини рота [6].

Метою даного дослідження було визначити особливості перебігу процесів диференціації букального епітелію в осіб чоловічої статі молодого віку в нормі.

МЕТОДИ ДОСЛІДЖЕННЯ. Матеріалом для дослідження слугував букальний епітелій, забраний у 25 осіб чоловічої статі молодого віку. Критерієм відбору осіб для обстеження була відсутність патологічного процесу в слизовій оболонці порожнини рота і тканинах пародонта, шкідливих звичок та супутньої соматичної патології. Епітелій забирали шпателем із подальшим перенесенням на предметне скельце та висушуванням при відкритому доступі повітря протягом 3-5 хв. Забарвлювали матеріал за Гімзою-Романовським із подальшим мікроскопічним та морфологічним аналізом з урахуванням відсоткового співвідношення різних форм епітеліоцитів у нормі.

З метою деталізації особливостей процесу зроговіння, який зумовлює клітинний склад даних цитограм, паралельно було проведено дослідження цитохімічної організації та співвідношення проміжних і поверхневих клітин епітелію ясен за допомогою реакції відновлення нітро-синього тетразолу (НСТ).

НСТ-тест характеризує активність ферментів, зокрема оксидаз фагосом, дегідрогеназ мітохондрій, а також гліколізу та пентозофос- 
фатного циклу, що відображає функціональний стан клітин. Застосований тест дає інформацію про функціонування одного з ключових ферментів системи тканинного дихання та окисного фосфорилювання - нікотинамід-флавінаденін-нуклеотидфосфат-оксидази, який відображає енергетичний потенціал клітини.

Зазвичай субстратом для НСТ-тесту є нейтрофільні гранулоцити, проте ми успішно застосували дану методику на різних класах епітеліальних клітин. НСТ, у разі взаємодії із цитоплазматичними органелами ясенних епітеліоцитів, а саме мітохондріями, ініціює зміну забарвлення в синій колір завдяки окисновідновним реакціям, що дає можливість оцінити класову належність клітин та їх енергетичний потенціал [7].

Статистичну обробку результатів виконано у відділі системних статистичних досліджень ДВНЗ “Тернопільський державний медичний університет імені І. Я. Горбачевського МОЗ України" в програмному пакеті Statsoft STATISTICA. Параметричні методи застосовували для показників, розподіл яких відповідав вимогам нормальності. Для оцінки характеру розподілу визначали коефіцієнт асиметрії та ексцес. Перевірку нормальності проводили за тестом асиметрії Шапіро-Вілка. Вірогідність відмінностей отриманих результатів для різних груп визначали за допомогою t-критерію Стьюдента. Відмінності вважали вірогідними при загальноприйнятій у медико-біологічних дослідженнях імовірності помилки $p<0,05$. Імовірність помилки оцінювали за таблицями Стьюдента з урахуванням кількості експериментальних груп. Коли закон розподілу статистичнодостовірно відрізнявся від нормального, роз-

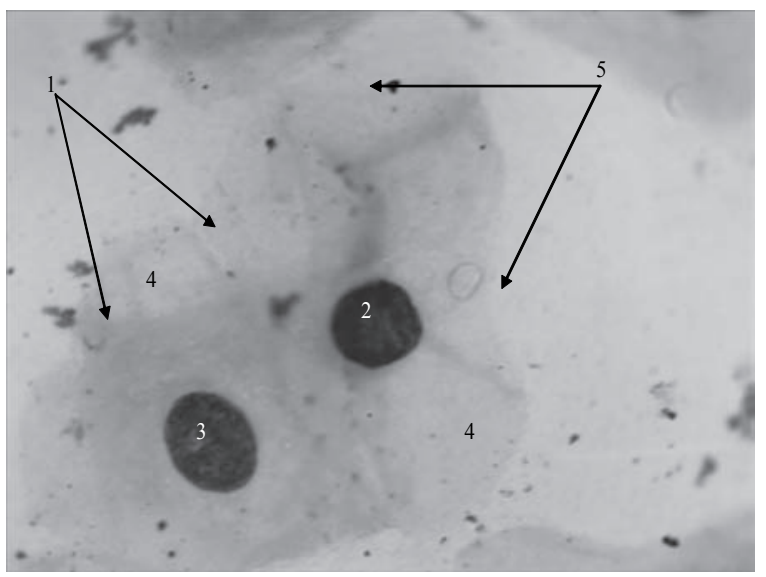

Рис. 1. Цитограма щоки. Забарвлення: за ГімзоюРомановським. Збільшення: $\times 400$ :

1 - проміжні клітини (базофільні); 2 - округла форма ядра проміжної клітини; 3 - овальна форма ядра проміжної клітини; 4 - цитоплазма проміжних клітин; 5 - полігональна форма клітини. раховували непараметричний критерій (U) Манна-Уітні як непараметричний аналог t-критерію Стьюдента.

РЕЗУЛЬТАТИ Й ОБГОВОРЕННЯ. КЛІТИННИЙ склад цитограм щоки осіб чоловічої статі молодого віку при забарвленні за Гімзою-Романовським представлений проміжними $(92,0 \pm 2,18)$ і поверхневими клітинами $(4,7 \pm 0,19)$, а також роговими лусочками $(3,3 \pm 0,14)$.

Проміжні клітини обстеженого контингенту осіб характеризуються порівняно великими розмірами, ядра округлої або ж овальної форми з везикулами та добре вираженими грудочками хроматину. Форма клітин полігональна, зі слабобазофільною цитоплазмою. Розташування клітини переважно скупчене (рис. 1).

Слід зауважити, що проміжні епітеліоцити складають абсолютну більшість клітинних елементів у цитологічних препаратах обстеженого контингенту осіб (рис. 2).

Слід відмітити наявність чітко виражених зерен глікогену в цитоплазмі проміжних епітеліоцитів щоки обстеженого контингенту осіб, що підтверджує результати дослідження попередників [1] стосовно здатності багатошарового плоского епітелію людини до синтезу та накопичення великої кількості даного метаболіту.

Зазвичай зерна глікогену у вигляді азурпозитивних гранул накопичуються в цитоплазмі клітин проміжного шару, проте іноді гранули візуалізуються і в поверхневих епітеліоцитах. При цьому цитоплазма характеризується ШИКпозитивною реакцією, що вказує на наявність у ній глікогену, тоді як ядрам властива розсіяна конденсація хроматину. НСТ-гранули у вигляді

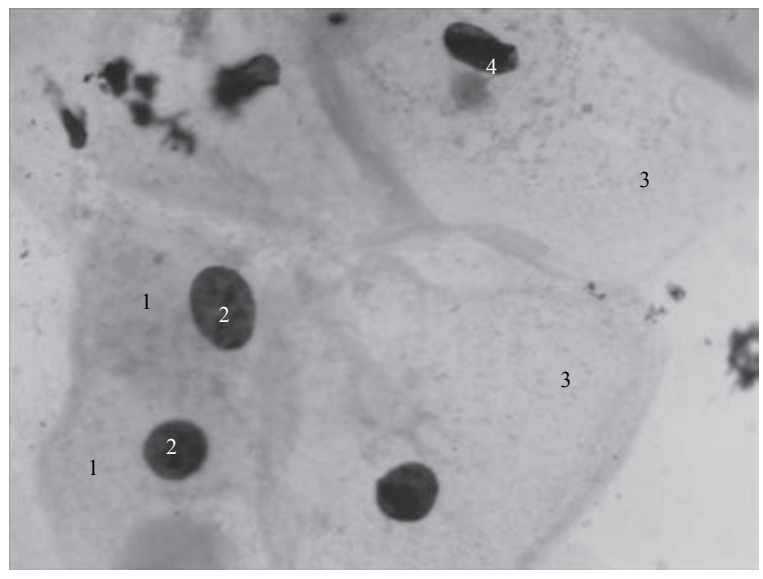

Рис. 2. Цитограма щоки. Забарвлення: за ГімзоюРомановським. Збільшення: $\times 400$ :

1 - проміжні клітини (слабобазофільні); 2 - ядро проміжної клітини; 3 - поверхневі клітини; 4 - пікнотичне ядро поверхневої клітини. 
блакитних скупчень зберігаються в невеликій кількості (рис. 3).

Поверхневі епітеліоцити мають більші розміри, ніж проміжні. Форма клітин полігональна, в цитоплазмі візуалізуються дрібні гранули кератогіаліну, ядра невеликих розмірів, здебільшого чітко округлі, іноді овальні темні пікнотичні. Цитоплазма даних клітин слабобазофільна, проте трапляються епітеліоцити з еозинофілією цитоплазми. В ядрах часто візуалізуються дрібні незабарвлені вакуолі, відмічають каріолізис, каріопікноз та каріорексис. У результаті фрагменти ядра повністю елімінуються із цитоплазми. Розташування поверхневих клітини переважно розрізнене (рис. 4).

У цитоплазмі візуалізуються поодинокі еозинофільні гранули, що вказує на слабку тенденцію до зроговіння даного типу епітеліоцитів

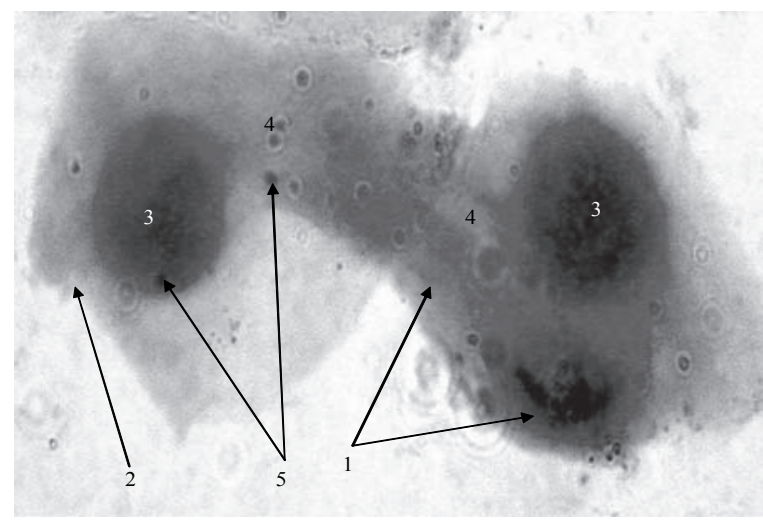

Рис. 3. Цитограма щоки. Забарвлення: НСТ+реактив Шифф-йодна кислота. Збільшення: ×1000:

1 - проміжні епітеліоцити (азурпозитивні); 2 - поверхневі епітеліоцити (азурпозитивні); 3 - розсіяний хроматин ядер; 4 - ШИК-позитивна гомогенна цитоплазма; 5 - НСТ-гранули.

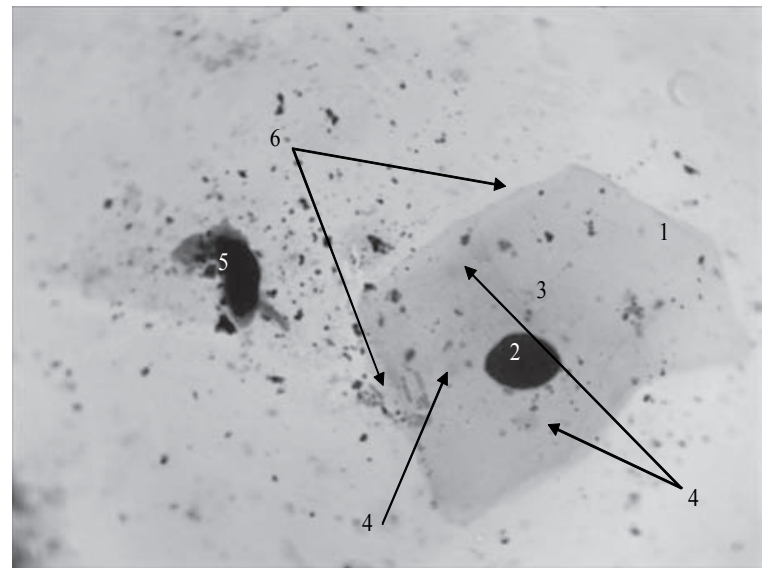

Рис. 4. Цитограма щоки. Забарвлення: за ГімзоюРомановським. Збільшення: $\times 400$ :

1 - поверхневий епітеліоцит (еозинофільний); 2 пікнотичне ядро; 3 - цитоплазма клітини; 4 - еозинофільні гранули; 5 - еліменований фрагмент ядра; 6 полігональна форма клітин. і характеризує процес кератинізації даного виду епітеліоцитів як апоптоз - генетично детерміновану загибель клітини.

3 метою ідентифікації механізмів зроговіння епітелію щоки осіб чоловічої статі молодого віку було проведено цитохімічні дослідження із застосуванням НСТ-тесту.

Цитохімічні дослідження дають можливість підтвердити механізми зроговіння епітелію незавершеним шляхом, оскільки НСТ-гранули зберігаються, що свідчить про явища їх фізіологічного некрозу - апоптоз (рис. 5).

У частині поверхневих клітин ядра втрачають чіткість форми та контурів і набувають вигляду ядерної тіні. У цитоплазмі візуалізуються поодинокі азурпозитивні гранули, наявність яких забезпечується накопиченням в них високоенергетичного вуглеводу глікогену. Iнтенсивність накопичення останнього в букальних епітеліоцитах значно нижча в обстеженого контингенту осіб порівняно 3 ідентичними клітинами в гендерному аспекті. Проте в цитоплазмі зберігаються гранули кератогіаліну та тонофіламентозні сітчасті комплекси, що свідчить про поетапний процес зроговіння даного типу клітин (рис. 6).

Особливістю цитограм букального епітелію обстеженого контингенту осіб є відсутність парабазальних клітин, що характеризує процес диференціації епітеліоцитів даної анатомічної ділянки в нормі. Звертає на себе увагу низький рівень контамінації мікроорганізмів на проміжних та поверхневих епітеліоцитах порівняно із цитограмами осіб жіночої статі, а в ряді цитограм - повна відсутність адгезії мікроорганізмів на поверхні клітини даних класів.

Слід відзначити наявність у цитограмах незначної кількості рогових лусочок, які представлені без'ядерними структурами, що в

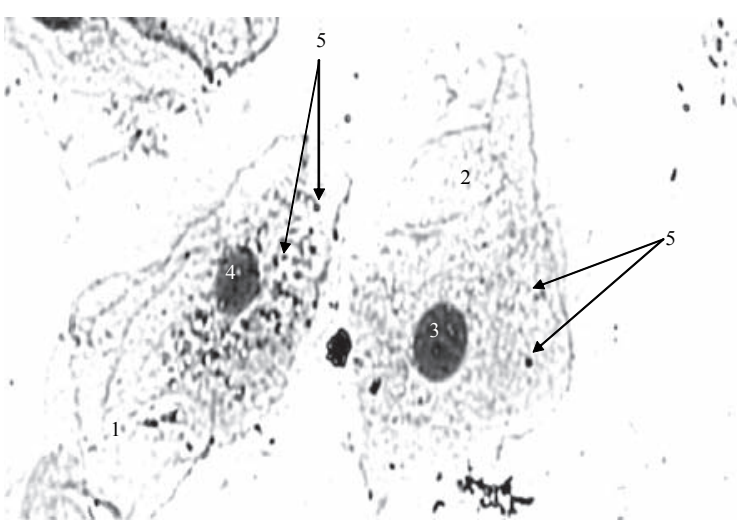

Рис. 5. Цитограма щоки. Забарвлення: НСТ-тест. Збільшення: ×1000:

1 - поверхневий епітеліоцит; 2 - проміжний епітеліоцит; 3 - ядро проміжного епітеліоцита; 4 - ядро поверхневого епітеліоцита; 5 - НСТ-гранули. 


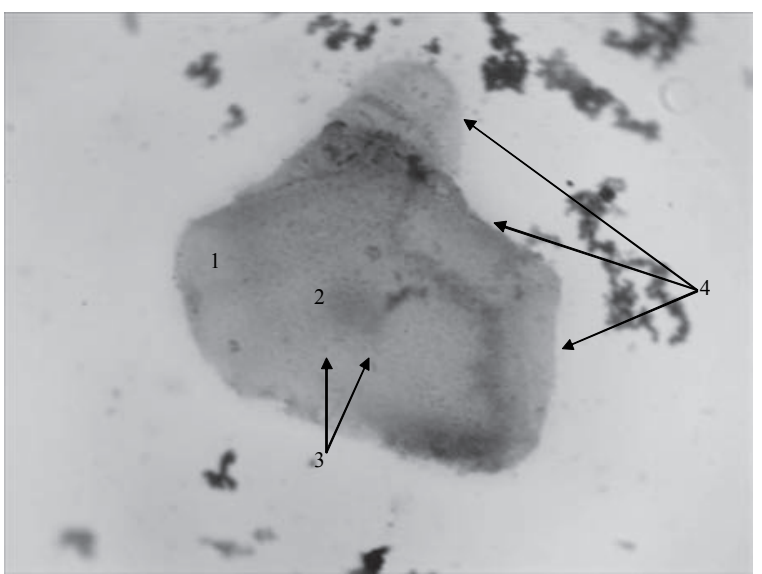

Рис. 6. Цитограма щоки. Забарвлення: за ГімзоюРомановським. Збільшення: $\times 400$ :

1 - поверхневий епітеліоцит (азурпозитивний); 2 ядерна тінь; 3 - поодинокі азурпозитивні гранули; 4 полігональна форма клітин.

процесі диференціації втратили ядро. Цитоплазма лусочок букального епітелію характеризується еозинофілією (рис. 7).

Так, у процесі вивчення особливостей перебігу процесів диференціації епітеліоцитів щоки осіб чоловічої статі молодого віку було визначено їх відсоткове співвідношення 0:92,0 $\pm 2,18: 4,7 \pm 0,19: 3,3 \pm 0,14$.

Одержані дані збігаються з відсотковим диференційованим співвідношенням епітеліоцитів багатошарового плоского епітелію щоки [1], проте результати наших досліджень вказують на вірогідне збільшення кількості зрілих форм епітеліоцитів у обстеженого контин-

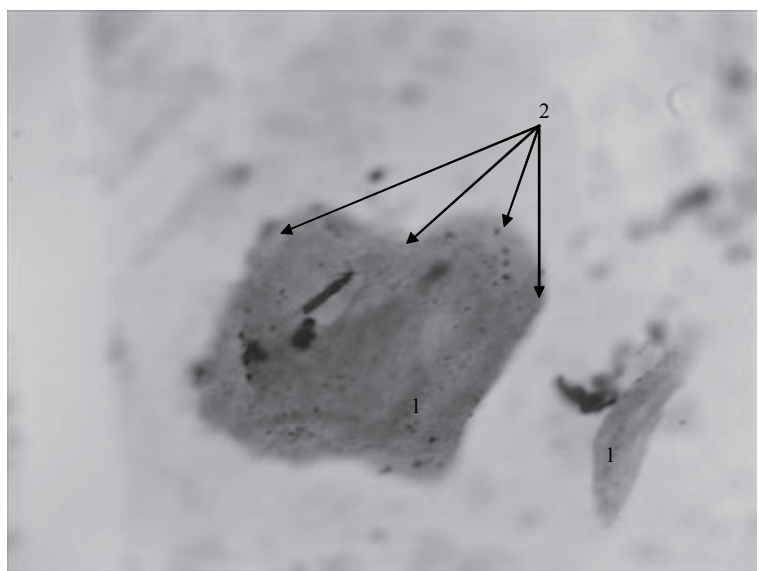

Рис. 7. Цитограма щоки. Забарвлення: за ГімзоюРомановським. Збільшення: $\times 400$ :

1 - рогові лусочки; 2 - гексагональна форма рогової лусочки щоки.

генту осіб. Специфічність цитологічних змін забезпечує, таким чином, бар'єрну функцію щоки шляхом тенденції до зроговіння, а отже, до десквамації епітелію даної анатомічної ділянки.

ВИСНОВКИ. Відсоткове співвідношення проміжних клітин дещо подібне, що характеризує на сьогодні нормальний перебіг процесу диференціації епітелію щоки в молоді та бар'єрну функцію букального епітелію осіб чоловічої статі за рахунок вірогідного збільшення кількості рогових лусочок та, як наслідок, процесу десквамації.

\section{СПИСОК ЛІТЕРАТУРИ}

1. Быков В. Л. Функциональная морфология эпителиального барьера слизистой оболочки полости рта / В. Л. Быков // Стоматология. - 1997. № 3. - С. 12-17.

2. Власова Л. Ф. Цитологический анализ поверхностных слоев эпителия слизистой оболочки рта / Л. Ф. Власова, Л. М. Непомнящих, Е. О. Резникова // Бюл. эксперим. биологии. - 2000. - № 1. С. $113-116$.

3. Гасюк Н. В. Эпителиоциты ротовой полости как маркеры молекулярно-генетических исследований [Электронный ресурс] / Н. В. Гасюк, О. Н. Бойченко, С. Б. Герасименко // Математическая морфология : электронный математический медикобиологический журнал. - 12, № 2. - Режим доступа к журн. : http: //www.smolensk.ru/user/sgma/ MMORPH/N-38-html/cont.htm.

4. Заверная А. М. Методы оценки и коррекции иммунных нарушений у больных с дистрофически- воспалительными и воспалительно-деструктивными заболеваниями пародонта и слизистой оболочки полости рта / А. М. Заверная, А. С. Волосовец, Т. Н. Андрусенко // Дентальные технологии. 2005. - № 5-6. - С. 13-15.

5. Ільченко В. І. Зміни слизової оболонки порожнини рота при деяких екзантематозних інфекціях / В. І. Ільченко, Ю. М. Вітко // Укр. стоматол. альм. 2010. - № 2, ч. 2. - С. 88-89.

6. Клеточный состав мазков со слизистой оболочки полости рта при стоматите / В. Н. Почтарь, А. П. Левицкий, В. Е. Завадский, Е. П. Пустовойт // Вісн. стоматол. - 2006. - № 3. - С. 19-22.

7. Пирс Э. Гистохимия / Э. Пирс. - М. : Изд-во иностр. литер., 1962. - 742 с.

8. Behavior of tight-junction, adherens-junction and cell polarity proteins during HNF-4alpha-induced epithelial polarization / S. Satohisa, H. Chiba, M. Osanai [et al.] // Exp. Cell. Res. - 2005. - № 310 (1). - P. 66-78. 
9. Schmalz G. Release of prostaglandin E2, IL-6 and IL-8 from human oral epithelial culture models after exposure to compounds of dental materials / G. Schmalz, H. Schweiki, K. A. Hiller // Eur. J. Oral. Sci. - 2000. - № 108. - P. 442-448.
10. The oral ecosystem: implications for education / H. Eriksen, V. Dimitrov, M. Rohlin [et al.] // J. Dent. Educ. - 2006. - 10, № 4. - P. 192-196.

Н. В. Гасюк

ТЕРНОПОЛЬСКИЙ ГОСУДАРСТВЕННЫЙ МЕДИЦИНСКИЙ УНИВЕРСИТЕТ ИМЕНИ И. Я. ГОРБАЧЕВСКОГО

\section{ЦИТОХИМИЧЕСКАЯ И ЦИТОЛОГИЧЕСКАЯ ХАРАКТЕРИСТИКА ПРОЦЕССОВ ДИФФЕРЕНЦИАЦИИ БУККАЛЬНОГО ЭПИТЕЛИЯ У ЛИЦ МУЖСКОГО ПОЛА МОЛОДОГО ВОЗРАСТА В НОРМЕ}

\section{Резюме}

В статье приведены результаты комплексного цитохимического и цитологического исследования клеточного состава буккального эпителия лиц мужского пола молодого возраста в норме. Полученные результаты позволяют констатировать преобладание зрелых форм эпителиоцитов в цитограммах, что обеспечивет, таким образом, барьерную функцию щеки путем тенденции к ороговению, инициируя десквамативные процессы эпителия данной анатомической области у обследованного контингента лиц.

КЛЮЧЕВЫЕ СЛОВА: эпителиоциты, клетки, цитоплазма, ядро, гранулы.

N. V. Hasyuk

I. YA. HORBACHEVSKY TERNOPIL STATE MEDICAL UNIVERSITY

\section{CYTOCHEMICAL AND CYTOLOGICAL OF PROCESSES OF DIFFERENTIATION OF BUCCAL EPITHELIUM IN YOUNGER MALES IN THE NORM CHARACTERISTIC}

\section{Summary}

In the article the results of a comprehensive study of cytochemical and cytological cellular structure of buccal epithelium of younger males norm were shown. The results make it possible to ascertain prefer mature forms of epithelial cells in cytohrams, thus ensuring the implementation of the barrier function of the cheek by a slight tendency to keratinization, initiating processes deskvamative epithelium of the anatomical regions in individuals surveyed contingent.

KEY WORDS: epithelial cells, cytoplasm, nucleus, granules.

Отримано 27.01.15

Адреса для листування: Н. В. Гасюк, Тернопільський державний медичний університет імені І. Я. Горбачевського, м. Волі, 1 , Тернопіль, 46001, Україна. 